DEPÓSITO LEGAL ZU2020000153

Esta publicación científica en formato digital

es continuidad de la revista impresa

ISSN 0041-8811

E-ISSN 2665-0428

Revista

de la

Universidad

del Tunlia

Fundada en 1947

por el Dr. Jesús Emrique Lossada

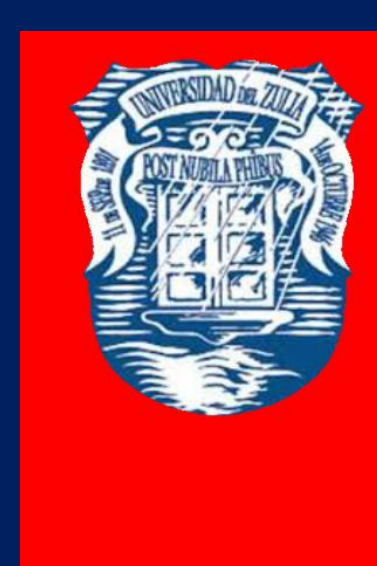

Ciencias

Sociales

y Arte

Aกัต 11 No 31

Septiembre - Diciembre 2021

Tercera ípoca

Maracailbo-Venezuela 


\title{
Psychological and pedagogical potential of life orientations of spouses with various dominant marital behavior
}

\author{
Marianna A. Latysheva * \\ Zumrud Z. Suleymanova ** \\ Patimat N. Magomedova*** \\ Sergey V. Kulikov ****
}

ABSTRACT

The article is devoted to the problem of transformation of family values, the emergence of new types of families in the context of modern marriage. The authors believe that in post-Soviet society in Russia, the axiological approach is the most heuristic in the study of marriage. The authors used a psychological analysis of the life-meaning orientations of spouses with a traditional type of marriage and spouses focused on voluntary childlessness. The results of the study showed that the specifics of life and life orientations of the husband and wife, their personal characteristics determine the attitudes and expectations of marital relations, the choice of the type of family. It was revealed that the life orientations of spouses who support voluntary childlessness are contradictory: men, when they are dissatisfied with their lives in the present and not confident in their abilities, focused on getting pleasure as the meaning of life here and now; and the wife, experiencing the riches of his life, demonstrating the confidence, commitment to the future, a higher meaning of life. Spouses from the traditional type of family are both happy with their lives. At the same time, husbands are characterized by an average level of meaningfulness of life, focus on the implementation of current tasks, and wives with a high sense of life are focused on the future, are confident in the possibility of building a life in accordance with their ideas about its meaning and life goals.

KEY WORDS: family, life meaning orientation, family types, voluntary childlessness, individual psychological characteristics of spouses, attitudes and expectations from marital relations, family values.

* PhD of Psychology, Psychology Department V.I. Vernadsky Crimean Federal University Simferopol, Russia, SPIN: 4595-2295, ORCID: http:/orcid.org/0000-0001-9827-7363

* Doctor of Pedagogical sciences, Professor, General Director Museum-ReserveEthnographic Complex "Dagestan Aul" Makhachkala, Russia, SPIN: 9966-9540

*** PhD of Pedagogy, Associate Professor Dagestan Institute of education development Methodist of the scientific and methodological Department Makhachkala, Russia, SPIN: 4938-4941

**** Candidate of Philosophy, Associate Professor, Associate Professor of the Department of Journalism of the Philological Faculty Peoples' Friendship University of Russia (RUDNuniversity) Moscow, Russia, ORCID: https://orcid.org/0000-0001-8815-0174

Recibido: 01/07/2020

Aceptado: 03/09/2020 


\section{Potencial psicológico y pedagógico de las orientaciones de vida de los cónyuges con diversos comportamientos maritales dominantes}

RESUMEN

El artículo está dedicado al problema de la transformación de los valores familiares, la aparición de nuevos tipos de familias en el contexto del matrimonio moderno. Los autores creen que en la sociedad postsoviética de Rusia, el enfoque axiológico es el más heurístico en el estudio del matrimonio. Los autores utilizaron un análisis psicológico de las orientaciones del significado de la vida de los cónyuges con un tipo de matrimonio tradicional y los cónyuges centrados en la falta voluntaria de hijos. Los resultados del estudio mostraron que las características específicas de la vida y las orientaciones de vida del esposo y la esposa, sus características personales, determinan las actitudes y expectativas de las relaciones matrimoniales, la elección del tipo de familia. Se reveló que las orientaciones de vida de los cónyuges que apoyan la ausencia voluntaria de hijos son contradictorias: los hombres, cuando están insatisfechos con su vida en el presente y no confían en sus capacidades, se centran en obtener el placer como sentido de la vida aquí y ahora; y la esposa, experimentando las riquezas de su vida, demostrando confianza, compromiso con el futuro, presenta un sentido superior de la vida. Los cónyuges del tipo de familia tradicional están felices con sus vidas. Al mismo tiempo, los esposos se caracterizan por un nivel promedio de significado de la vida, se enfocan en la implementación de las tareas actuales y las esposas con un alto sentido de la vida se enfocan en el futuro, confían en la posibilidad de construir una vida de acuerdo con sus ideas sobre su significado y objetivos de vida.

PALABRAS CLAVE: familia, orientación al sentido de vida, tipos de familia, ausencia voluntaria de hijos, características psicológicas individuales de los cónyuges, actitudes y expectativas de las relaciones maritales, valores familiares.

\section{Introduction}

The purpose of this study is to analyze the transformation of family values in modern conditions, as well as to consider new types of families in the context of modern marriage in the South of Russia. Over a long period of development of society, the family was a stable microsystem, the most important functions of which were the birth and upbringing of children, the transmission to the next generation of values and traditions accumulated by humanity (Druzhinin, 2008). But at the context of global sociocultural processes the family system as a social phenomenon is undergoing changes. However, over the past few decades 
REVISTA DE LA UNIVERSIDAD DEL ZULIA. $3^{a}$ época. Año 11 N 31, 2020

Marianna A. Latysheva et al. // Psychological and pedagogical potential of life orientations ...509-523

DOI: http://dx.doi.org/10.46925//rdluz.31.33

the transformations of the institution of a family is rapid so match that it can be considered as crisis (Bolshunova, 2018; Vildanova, 2017; Kiseleva, 2016).

In building marital relations, the important role is played the values and meanings of the life of partners, their personal characteristics, the "model" of role-playing behavior and etc. It should be noted that many of our contemporaries of early and middle adulthood are far from the representation about traditional model of the family. Individualistic tendencies in spouses' life values have been greatly strengthened, their moral principles have decreased, family ties have been weakened and etc. Increasingly, a modern man in the role of a husband does not consider responsibility for the family as a value, does not realize its correlation with debt and chief yourself at the family system. A woman in a marital relation, as a rule, moves away from resolving problems by the compensatory behavior, rationalizing them, or conflicts, which often becomes the cause of divorces. In this regard, questions remain about what are the life-meaning orientations of spouses in the regions of the Russian Federation at the our moment, to what extent the individual psychological characteristics of spouses and the degree of meaningfulness of their life determine the choice of family type, are reflected in attitudes and expectations from marital relations.

\section{Theoretical and methodological bases}

The methodological basis of empirical research was the ideas of philosophers and psychologists about the meaning of human life, fundamental works about the semantic sphere of personality: N. A. Berdyaev, A. I. Vvedensky, V. V. Rozanov, P. A. Florensky, S. L. Frank; K.A. Abulkhanova-Slavskaya, A.G. Asmolov, B.S. Bratus, F.E. Vasilyuk, V.K. Vilyunas, E.I. Isaev, A.N. Leontyev, D.A. Leontyev, V.I. Slobodchikov, M.S. Yanitsky, R. May, V. Frankl, I. Yalom.

The organization and methods of research are determined by its goal and objectives of theoretical and practical problems. Theoretical research methods were used: analysis of philosophical, psychological literature, scientific periodicals, dissertations. Practical methods included: observation, questioning, testing (Life Meaning Orientations Test (D.A. Leontiev); Value orientations in the field of family relations questionnaire; Role expectations and claims in marriage questionnaire (Volkova A.N); Individual-typological questionnaire L.N. Sobchik (ITQ). 
REVISTA DE LA UNIVERSIDAD DEL ZULIA. $3^{a}$ época. Año 11 N 31, 2020 Marianna A. Latysheva et al. // Psychological and pedagogical potential of life orientations ...509-523

DOI: http://dx.doi.org/10.46925//rdluz.31.33

The study of the value-semantic sphere of personality is one of the most significant and complex problems of psychology both theoretically and in practical terms (Leontiev, 2007; Lipova, 2014). Despite several differences in interpretation, most scholars agree that the meaning of life, value orientations determine the general orientation of an individual's activity and regulate its behavior. Significantly expanded the understanding of this problem by the work of D. A. Leontiev. In particular, the concept of meaning-life orientations introduced by the author in Russian psychology made it possible to reveal the time perspective of meaningfulness of life by a person, the conviction that control is possible, including and from her own side (Leontiev, 2000).

It should be noted that the change in the meanings of the modern personality, closely related to the time perspective, has also significantly affected the attitude towards marriage and the fulfillment of family responsibilities. So, both spouses began to strive to be realized in the professional sphere, and women aspired to leadership at own family (Sadovnikova, 2015). The number of types of families in which the creation of a family is based not on an economic, but mainly on an emotional, psychological component has increased (Danina et al, 2016; Schneider, 2007).

Statistical methods were used to process the results: the method $\varphi$ - Fisher, correlation analysis. The validity of the proposed provisions, the reliability of the results and conclusions are ensured by the rigor of the conceptual apparatus of the study, a clear definition of the subject area and objectives of the study, a theoretical analysis of the problem, the use of a set of diagnostic methods of psychological research, and representativeness of the sample of persons participating in the study.

\section{Results}

As can be seen from table l, among the spouses-supporters of voluntary childlessness, one can note a pronounced discrepancy in the meaning of life orientations. So, the husband is focused on receiving pleasure as the highest good and meaning of life, although in the present his experiences dissatisfaction own life, he does not believe in own abilities; that lifecontrol is possible, and that it makes no sense to make long-term plans. On average, husbands have a low level of consciousness of the life. Their wife's, opposite, have demonstrated the high level of consciousness of the life. They are confident that they have sufficient freedom of 
REVISTA DE LA UNIVERSIDAD DEL ZULIA. 3ª época. Año 11 N 31, 2020

Marianna A. Latysheva et al. /// Psychological and pedagogical potential of life orientations ...509-523

DOI: http://dx.doi.org/10.46925//rdluz.31.33

choice to build life in accordance with their goals, objectives and ideas about its meaning, they feel emotional fullness, the fullness of their lives and are directed to the future.

Table 1. Results of the Meaning-of-Life Orientations D. A. Leontiev of spouses from different types of families (average values)

\begin{tabular}{|c|c|c|c|c|}
\hline $\begin{array}{c}\text { Subjects } \\
\text { Subscales }\end{array}$ & TF H & TF W & VCF H & VCF W \\
\hline Purposes in life & 32,3 & 27,4 & 37,3 & 37,1 \\
\hline $\begin{array}{c}\text { Life process } \\
\text { Results the life }\end{array}$ & 26,5 & 25,6 & 34,7 & 34 \\
\hline $\begin{array}{c}\text { Locus of Control-I am } \\
\text { (the locus of inner } \\
\text { control) }\end{array}$ & 17,8 & 17,1 & 24,7 & 25,1 \\
\hline Locus of control - life & 27,2 & 24,3 & 36,8 & 36,6 \\
\hline $\begin{array}{c}\text { General indicator } \\
\text { meaning of life (ML) }\end{array}$ & 96,2 & 88,4 & 119,4 & 120,5 \\
\hline
\end{tabular}

Note: VCF - voluntary childlessness family (H - husband, W - wife); TF - traditional family ( $\mathrm{H}$ - husband, $\mathrm{W}$ - wife)

Among spouses of supporters of a traditional family, there are much fewer discrepancies. Husbands are generally satisfied with their life, both in the past segment and in the present; consider it interesting, quite rich. In their opinion, they are able to control certain areas of life and are ready to implement the tasks set.

Table 2. Results of Value orientations in the field of family relations questionnaire of spouses from different types of families (\%)

\begin{tabular}{|c|c|c|c|c|}
\hline Scales & TF H & TF W & VCF H & VCF W \\
\hline freedom at a family & 3,6 & 3,1 & 3,3 & 2,6 \\
\hline Experience in love & 1,2 & 2,3 & 1,7 & 1,6 \\
\hline Work Achievements & 1,7 & 1,7 & 3,5 & 3,6 \\
\hline $\begin{array}{c}\text { Flexible general } \\
\text { upbringing }\end{array}$ & 3 & 3,5 & 3 & 2,6 \\
\hline
\end{tabular}


REVISTA DE LA UNIVERSIDAD DEL ZULIA. 3época. Año 11 N³1, 2020

Marianna A. Latysheva et al. /// Psychological and pedagogical potential of life orientations ...509-523

DOI: http://dx.doi.org/10.46925//rdluz.31.33

\begin{tabular}{|c|c|c|c|c|}
\hline $\begin{array}{c}\text { Freedom of sexual } \\
\text { expression }\end{array}$ & 3,2 & 1,6 & 3,5 & 3,2 \\
\hline $\begin{array}{c}\text { Self-expression of } \\
\text { personality }\end{array}$ & 1,5 & 1,7 & 3,7 & 3,7 \\
\hline $\begin{array}{c}\text { The breadth of } \\
\text { external contacts of the } \\
\text { family }\end{array}$ & 1,9 & 2 & 2,6 & 2,5 \\
\hline $\begin{array}{c}\text { Strive for } \\
\text { Achievements their } \\
\text { children to great } \\
\text { success }\end{array}$ & 3,2 & 3,2 & 3,3 & 3,2 \\
\hline Family commitment & 2,9 & 2,5 & 1,6 & 1,6 \\
\hline Early marriage & 1,5 & 1,5 & 1,4 & 1,4 \\
\hline $\begin{array}{c}\text { Order and discipline at } \\
\text { family }\end{array}$ & 2,9 & 2,5 & 2,8 & 3,2 \\
\hline Fidelity in love & 2,7 & 3 & 2,1 & 1,5 \\
\hline Depth of family ties & 2,9 & 3,2 & 1,5 & 1,3 \\
\hline $\begin{array}{c}\text { Rigid, rigorous special } \\
\text { upbringing }\end{array}$ & 2,3 & 2,1 & 2,8 & 2,6 \\
\hline Sexual restraint & 2,4 & 3 & 1,7 & 1,5 \\
\hline $\begin{array}{c}\text { Self-sacrifice for } \\
\text { Children }\end{array}$ & 3 & 3,5 & 0,5 & 0,8 \\
\hline $\begin{array}{c}\text { Restriction and depth } \\
\text { of external family ties }\end{array}$ & 3 & 2,4 & 1,9 & 2,4 \\
\hline $\begin{array}{c}\text { Realistic expectations } \\
\text { based on children's } \\
\text { abilities }\end{array}$ & 1,7 & 1,9 & 2,5 & 2,3 \\
\hline $\begin{array}{c}\text { Commitment to the } \\
\text { public interest }\end{array}$ & 2,4 & 2,3 & 2 & 1,7 \\
\hline Mature Marriage & 1,7 & 1,6 & 2,5 & 2,3 \\
\hline
\end{tabular}

Note: VCF - voluntary childlessness family ( $\mathrm{H}$ - husband, $\mathrm{W}$ - wife); TF - traditional family ( $\mathrm{H}$ - husband, $\mathrm{W}$ - wife)

At the same time, spouses from traditional families do not set themselves serious goals in the future and are characterized by an average level of meaningfulness in life. Among wives from this type of family, predominantly high indicators were found on all scales of the test of 
REVISTA DE LA UNIVERSIDAD DEL ZULIA. 3ª época. Año 11 N 31, 2020

Marianna A. Latysheva et al. /// Psychological and pedagogical potential of life orientations ...509-523

DOI: http://dx.doi.org/10.46925//rdluz.31.33

meaning-life orientations, which allows us to determine the relationship in a married couple as complementary.

As can be seen from table 2, among the value orientations in family relations, spouses who support voluntary childlessness are more focused on self-expression of personality and achievement in work; prefer freedom of sexual expression; more important for them is the breadth of external contacts of the family. Spouses are not ready for self-sacrifice for the sake of children, do not show commitment to the interests of the family and do not seek deep family ties; prefer marriage in adulthood and at the same time value discipline and order in the family.

Spouses who support a traditional family are willing to sacrifice themselves for their children, prefer sexual restraint, fidelity in love and the depth of family ties, and also value discipline and order in the family. At the same time, in husbands from a traditional family, the attitude to the spouse depends more on satisfaction with sexual intercourse (at $\mathrm{p}=0.05$ ). They attach great importance to mutual tolerance, care and attention than male proponents of voluntary childlessness (see Table 2).

Analyzing the degree of coordination of the family values of the husband and wife in both subgroups, it can be noted that in the pairs there is a fairly high socio-psychological compatibility (table 3). Significant areas of family life for spouses with a focus on voluntary childlessness can be called such as personal identification, social activity, emotionalpsychotherapeutic, intimate-sexual, and external attractiveness.

As you can see, they expressed the attitude towards personal identification with a marriage partner, the coincidence of a commonality of interests, needs, value orientations, ways of forwarding, the presence of a spouse's professional interests, an active public role. It is important to provide moral and emotional support, the presence of a "psychotherapeutic atmosphere" in the relationship. At the same time, the spouse expects his wife to be an emotional leader. At the same time, the household function of the family is important for the wife and she expects that it is the spouse who will take responsibility and work for household affairs in the family. 
REVISTA DE LA UNIVERSIDAD DEL ZULIA. 3ª época. Año 11 N 31, 2020

Marianna A. Latysheva et al. // Psychological and pedagogical potential of life orientations ...509-523

DOI: http://dx.doi.org/10.46925//rdluz.31.33

Table 3. The results of the Role expectations and claims in marriage questionnaire (A.N. Volkova) of spouses from different types of families (average values)

\begin{tabular}{|c|c|c|c|c|c|c|}
\hline & \multicolumn{2}{|c|}{ SFVh } & \multicolumn{2}{c|}{ SFVw } & \multicolumn{2}{c|}{ CFV } \\
\hline Family Values Scales & TF & VCF & TF & VCF & TF & VCF \\
\hline Intimate -sexual & 6 & 5,4 & 2,9 & 6,6 & 3,1 & 1,2 \\
\hline Personal identification & 7,4 & 7 & 6,9 & 7,2 & 0,5 & 0,2 \\
\hline $\begin{array}{c}\text { Housekeeping and } \\
\text { mode of life }\end{array}$ & 7,5 & 3,5 & 6,1 & 5,5 & 1,4 & 2 \\
\hline Parenting & 7,4 & 3,5 & 7 & 3,1 & 0,4 & 0,4 \\
\hline Social activity & 5,7 & 7,9 & 5,2 & 7,3 & 0,5 & 0,6 \\
\hline $\begin{array}{c}\text { Emotionally } \\
\text { psychotherapeutic }\end{array}$ & 7 & 7,8 & 5 & 6,8 & 2 & 1 \\
\hline Sex appeal & 4,9 & 5,4 & 4,4 & 6,6 & 0,5 & 1,2 \\
\hline
\end{tabular}

Note: SFVh and SFVw - indicators on the scales of family values of husband and wife, CFV consistency of family values of spouses.); VCF - voluntary childlessness family, TF traditional family ( $\mathrm{H}$ - husband, $\mathrm{W}$ - wife)

Significant areas of family life for both spouses of the traditional type are household, personal identification, parental and educational, and social activity (Rusakova et al., 2019; Stoykov, 2019). That is, spouses are focused on the availability of household skills in the spouse, the coincidence of common interests, primarily parenting, as the main family value, on professional and social activity, understood as a stabilizer of marriage and family relations.

At the same time, the intimate-sexual and emotional-psychotherapeutic spheres are also important for the husband. In a traditional family, the husband considers sexual harmony an important condition for marital happiness and expects that his wife will ensure the psychological climate of the family (Khachmafova et al., 2017). Attention is drawn to a slight excess of the indicator of consistency on the scale of significance of sexual relations in the marriage among partners of a traditional family. Comparison with the results of the test "Value orientations in the field of family relations" indicates the presence of claims on this issue by the spouse, which is likely to subsequently cause family conflicts.

It was revealed that among spouses from families with a focus on voluntary childlessness, more pointed features such as extraversion, spontaneity and sensitivity $(\mathrm{p}=$ 
0.05), as well as aggressiveness, rigidity and unstable, which characterize them as individuals prone to leadership, are significantly more common conflicts, decisive, liberated in selfpresentation, neglecting conventions and prohibitions, easily related to existing problems, motivated by achievements, painfully experiencing failures.

The accentuated feature that most often prevails among wives is rigidity, which characterizes them as stubborn in achieving their goals, stubborn in upholding their point of view, envious of other people's glory and wealth, striving for supremacy, jealous of friendship and love, aggressive in upholding their right (table 4).

Among spouses from traditional families in a pointed form, there are such traits as aggressiveness, rigidity and unstable, much more often, compared with husbands from the second type, introversion (at $\mathrm{p}=0.05)$.

Table 4. The results of the individual typological questionnaire of spouses from traditional families and spouses of voluntary childlessness (average values)

\begin{tabular}{|c|c|c|c|c|c|c|c|c|}
\hline & \multicolumn{2}{|c|}{ TF H } & \multicolumn{2}{c|}{ TF W } & \multicolumn{2}{c|}{ VCF H } & \multicolumn{2}{c|}{ VCFW } \\
\hline Scales & A & B & A & B & A & B & A & B \\
\hline Extroversion & 2,5 & & 4,4 & & & 6 & 2,4 & \\
\hline Spontaneity & & 4,7 & & 5 & & 6,8 & 3,9 & \\
\hline Aggressiveness & & 5,5 & 4,6 & & & 5 & 3,8 & \\
\hline Rigidity & & 6,4 & & 5,4 & & 6,1 & & 5,6 \\
\hline Introversion & & 6 & 4,3 & & 4 & & 3,9 & \\
\hline Sensitivity & & 4,7 & 4,1 & & & 6 & 4,2 & \\
\hline Anxiety & 4 & & 4 & & 3,6 & & 3,8 & \\
\hline Unstable & & 5,1 & & 5,1 & & 5 & 2,4 & 4,9 \\
\hline
\end{tabular}

Note: A - balance of properties; B - pointed accentuated features; C - excessively expressed, desadaptive properties; VCF - voluntary childlessness family, TF - traditional family (H husband, $\mathrm{W}$ - wife)

This characterizes them as individuals prone to the accumulation of negative emotions, affective outbursts, unpredictable reactions to stress. Wife's are dominated by such pointed features as rigidity, and significantly more often spontaneity and unstable $(\mathrm{p}=0.05)$. This 
REVISTA DE LA UNIVERSIDAD DEL ZULIA. $3^{a}$ época. Año 11 N 31, 2020

Marianna A. Latysheva et al. // Psychological and pedagogical potential of life orientations ...509-523

DOI: http://dx.doi.org/10.46925//rdluz.31.33

characterizes them as decisive, enterprising, eager to act in their own way, to command, persistent in achieving the goal, rather conflicting, prone to hysterical manifestations.

Correlation analysis revealed a number of positive relationships between such indicators as goals in life and the locus of control of I, goals in life and the locus of control life $(\mathrm{r}=0.67$, at $\mathrm{p}=0.05)$; life productivity and self-expression of an individual $(\mathrm{r}=0.61$, at $\mathrm{p}=$ $0.05)$; experience in love and self-expression of personality $(\mathrm{r}=0.7$, at $\mathrm{p}=0.05)$; the locus of control of I and the desire for children to achieve great success ( $r=0.67$, at $\mathrm{p}=0.05)$; goals in life and realistic expectations based on children's abilities $(r=0.58$, at $\mathrm{p}=0.05)$; order and discipline in the family and the depth of family ties $(r=0.67$, at $\mathrm{p}=0.05)$.

The obtained relationships confirm the fact that the higher the meaningfulness of life, its direction to the future, the more people feel like a strong personality to build a life path in accordance with their goals, able to experience the emotional richness of each day lived, evaluate their life as interesting and productive. At the same time, the key to the ideas about its meaning are the opportunities and achievements of children, order and discipline in the family, and the depth of family ties. Of course, our study does not exhaust this issue, but allows us to fix its multidimensionality.

\section{Discussion}

We are looking at changes in the family structure in the South of Russia, as this region is characterized by a traditional Patriarchal way of life. In a sense, some families continue to live as well, as colleagues from other Patriarchal countries point out (Sheikh, Suleman et al, 2019). Researchers from Islamabad emphasize that women in Pakistani families are oppressed much more often, due to confessional, traditional and other factors. But family relationships are undergoing transformation even in such difficult conditions (Sheikh, Suleman et al, 2019).

Among them is such a type of family as supporters of voluntary childlessness, delaying or completely excluding the birth of children from their plans. Conscious refusal of men and women of childbearing age from reproductive behavior, arising as a phenomenon at the 70 -s. of the last century, is being intensively distributed, including in Russia, and in the framework of the social and demographic policy of our state, this process acquires a special sound. This is not to say that this is a distinctive feature of Russia alone. As a rule, socio-economic 
REVISTA DE LA UNIVERSIDAD DEL ZULIA. $3^{a}$ época. Año 11 N 31, 2020

Marianna A. Latysheva et al. // Psychological and pedagogical potential of life orientations ...509-523

DOI: http://dx.doi.org/10.46925//rdluz.31.33

disasters provoke an increase in crime and the flourishing of deviant behaviors. Venezuela is experiencing the same upheaval in the social sphere, that of Russia (Gámez, 2014).

The above trends are also observed in the works of foreign colleagues. It should be noted that studies of families focused on the conscious abandonment of the parent's role (Pelton and Hertlein, 2011), satisfaction with marital relations and etc., conducted primarily in the field of sociology (Rick and Meisenbach, 2011).

The American researcher L. Ashburn-Nardo emphasizes that the results on the transformation of goals in the modern family empirically prove the perception of parental responsibilities as a moral imperative (Ashburn-Nardo, 2017). It was the first time that she received evidence of changes in meaning-orientation goals in modern us spouses.

It is believed that Russia has a more traditional Patriarchal way of life (Bolshunova, 2018), which is characterized by conservatism (Kislov, 2015). An analysis of a few works devoted to the phenomenon of childfree showed that its appearance is associated with the transition of civilization to the postmodern era and the inversion of the hierarchy of values, traditional stereotypes (Polutova and Zhanbaz, 2015). Despite the interest in such a strategy of behavior on the part of philosophers, sociologists, culturologists, psychological studies of this phenomenon are still few, especially in the axiological aspect (Kiseleva, 2016). However, our research suggests the opposite.

Blackstone A. and Mahala D. S. (2016) rightly emphasize that modern media is transforming attitudes to parenthood by equating having children with buying pizza, which ultimately changes the very idea of family. These aspects of transformation are also pointed out by Russian researchers who catalogued transformation matrices in the social structure of the family and society (Karabulatova et al, 2017). Jones T. (2014) analyzed the child-free movement and came to a reasonable conclusion about the protest of such behavior, since representatives of the movement believe that everyone is free to decide whether they want to become a parent, and no one has the right to influence their decision in any way. I must say that the advertised freedom of choice transforms the biologically predetermined framework in the direction of changing social and gender identity. This problem is widely discussed in society and scientific circles, as it affects the basic foundations of human existence as a species (Luchinskaya et al., 2018).

The social aspect of the conscious choice of childlessness is also pointed out by other researchers who note the persistence of negative stereotypes in the environment about 
REVISTA DE LA UNIVERSIDAD DEL ZULIA. $3^{a}$ época. Año 11 N 31, 2020

Marianna A. Latysheva et al. /// Psychological and pedagogical potential of life orientations ...509-523

DOI: http://dx.doi.org/10.46925//rdluz.31.33

childless adults, although their acceptance has increased in recent decades. Negative biases «against parents, especially mothers, are particularly important in the context of work» (Koropeckyj-Cox et al., 2018).

As for childfree communities, forums, and similar places of communication, their existence is no worse, or more stupid, than the resources of vegetarians, anti-Smoking in public places, anti-globalists, animal rights advocates, or opponents of abortion. You can list a hundred advantages of childlessness, but the basic reason is a simple reluctance to become a parent. Childfree believe that everyone should live their life, not the life of a child. These and other researchers have noted that the childfree are less "socially comfortable", they increasingly characteristic of selfishness and individualism, even infantilism (Kamzina, Samykina, 2014). Yes, the childfree are selfish, but they are not going to hide it. They really live for their own pleasure and get the most out of life, and do not spend their lives on problems related to the birth and upbringing of children.

Research conducted in different countries highlights the following trends: everyone has the full right to live the way they want. And you don't always need a child to justify your existence. And isn't it worse when a child becomes a tool to prove to everyone their worth and importance in society? Isn't it worse when a child is used as an excuse to keep a man? Isn't it worse when parents try to assert themselves at the expense of their child and manipulate others by referring to them? In this context, not having children if you don't want to is at least fair. In the context of the pandemic, attitudes towards marriage and childbearing have changed for some young people, but the majority have remained committed to their beliefs.

\section{Conclusion}

The results of an empirical research indicate that the life meaning orientations, attitudes and expectations from marital relations, family values at the of spouses-supporters of voluntary childlessness and spouses with an orientation to the traditional type of family are differenced.

Thus, it has been shown that husbands proponents of voluntary childlessness do not adequately comprehend their lives in general, are focused on receiving pleasure as the highest good and meaning of life, they are convinced of the inability of a person to control life, they 
REVISTA DE LA UNIVERSIDAD DEL ZULIA. 3ª época. Año 11 N 31, 2020

Marianna A. Latysheva et al. // Psychological and pedagogical potential of life orientations ...509-523

DOI: http://dx.doi.org/10.46925//rdluz.31.33

are dissatisfied with their life in the present. They are prone to leadership, conflict, neglect rules and prohibitions, superficial, motivated at the achieves and painfully fail. Women, who prefer voluntary childlessness, have a high-level life meaning orientations, experience the emotional richness of their lives, are directed to the future. They are persistent in achieving the purpose, envious, strive for supremacy, aggressive in defending their rights. In family relationships, wifes of voluntary childlessness are focused on self-expression of an individual and achievements in work, the breadth of external contacts of the family, freedom of sexual expression, and are not ready for self-sacrifice for the sake of children (Antonenko, 2015). Despite the rather high socio-psychological compatibility of spouses who support voluntary childlessness, their life meaning orientations are noticeably inconsistent.

Husbands from a traditional family are characterized by an average level of life meaning orientations, are satisfied with their life, consider it quite interesting and rich in their opinion, they are able to control certain areas of life and are ready to implement the tasks set. Wifes from a traditional family also have a high level of life meaning orientations, are oriented towards the future, and are satisfied with the richness of their lives. Wifes are characterized entrepreneurial, self-will, rather conflicting, and prone to hysterical manifestations. Significant spheres of family life for both spouses of the traditional type are the presence of housekeeping and mode of life skills, community of interests, focus on parenthood, professional and social activity, as stabilizers of marriage and family relations. With enough socio-psychological compatibility, greater coherence of life meaning orientations of spouses from a traditional family, the area that is vulnerable in family relations is intimate-sexual (Serebryakova et al., 2019).

Thus, a comparative analysis convincingly showed that the personality traits of the future husband or wife, the specifics of their life meaning orientations determine the attitudes and expectations from the marital relations, and the choice of family type.

\section{Acknowledgments}

The authors of the article express their deep gratitude undergraduate of Psychology Department "V.I. Vernadsky Crimean Federal University", E. Tartynskaya and to all the participants of the experiment. 
REVISTA DE LA UNIVERSIDAD DEL ZULIA. $3^{a}$ época. Año 11 N 31, 2020

Marianna A. Latysheva et al. // Psychological and pedagogical potential of life orientations ...509-523

DOI: http://dx.doi.org/10.46925//rdluz.31.33

\section{References}

Antonenko, N.V. (2015). Family identity of men and women. Questions and answers, Psychological problems of the modern family: a collection of theses, 450-456.

Ashburn-Nardo, L. (2017). Parenthood as a moral imperative? Moral outrage and the stigmatization of voluntarily childfree women and men. Sex roles, 76 (5-6), 393-401.

Blackstone, A., Mahala, D.S. (2016). There's More Thinking to Decide. How the Childfree Decide Not to Parent". The Family Journal, 24 (3), 296-303.

Bolshunova, T.V. (2018). Childfree Phenomenon: Microsociological Analysis. University Herald, 4, 145-149.

Danina, M.M., Kiselnikova (Volkova), N.V., Golzickaya, A.A., Kuminskaya, E.A., Markova, S.V., Karpinskiy, K.V., Kolyshko, A.M. (2016). The current state of research in the field of regulation of the reproductive behavior of spouses. National Psychological Journal, 2 (22), 73-83.

Druzhinin, V.N. (2008). Family Psychology. St. Petersburg: Peter.

Jones, T. (2014). Single and Childfree: Reassessing Parental and Marital Status Discrimination. Ariz, 46, 1253.

Kamzina, O.A., Samykina, N.Yu. (2014). Study of life scenarios in representatives of the childfree community. Bulletin of the Samara State University, 1, 213-222.

Karabulatova I., Vildanov Kh., Zinchenko A., Vasilishina E., Vassilenko A. (2017). Problems of transformation matrices modern multicultural identity of the person in the variability of the discourse of identity Electronic Information Society. Pertanika Journal of Social Science $\&$ Humanities, 2017, 25(S). 1-16.

Khachmafova, Z.R., Karabulatova, I.S., Serebryakova, S.V., Zinkovskaya, A.V., Ermakova, E.N. (2017). The Specifics of an Estimate discourse of gender stereotypes in small forms of Folklore in a Network Discourse of Electronic and Information society at the Beginning of 2lct Century. Pertanika Journal of Social Science \& Humanities, 25 (S) Jul., 137-150.

Kiseleva, E.V. (2016). Family as a sociocultural value. Bulletin of Slavic cultures, 1 (39), 76-83.

Kislov, A.G. (2015). Childfree as a social symptom. Ural State Pedagogical University, 2, 220226.

Koropeckyj-Cox, T., Çopur, Z., Romano, V., Cody-Rydzewski, S. (2018). University students' perceptions of parents and childless or childfree couples. Journal of Family Issues, 39 (1), 155-179.

Leontiev, D.A. (2000). Life meaning orientation test (LMT). Moscow: Nauka.

Leontiev, D.A. (2007). Psychology of meaning: nature, structure and dynamics of semantic reality. Moscow: Nauka.

Lipova, O.A. (2014). The theory of meaning as the basic component of the national general psychological theory. Bulletin of the Taganrog Institute named by A.P. Chekhov, 2. 
REVISTA DE LA UNIVERSIDAD DEL ZULIA. 3ª época. Año 11 N 31, 2020

Marianna A. Latysheva et al. // Psychological and pedagogical potential of life orientations ...509-523

DOI: http://dx.doi.org/10.46925//rdluz.31.33

Luchinskaya, E.N., Karabulatova, I.S., Zelenskaya, V.V., Golubtsov, S.A. (2018). Characteristics of Image of the Russian Family in Modern Advertising Discourse. Astra Salvensis, 11 (1), 699-714.

Martínez Gámez, A.E. (2014). Determinantes de la criminalidad en Venezuela: un análisis para el período 1970-2012. Revista de la Universidad del Zulia., 5 (13), 11-34. https:/produccioncientificaluz.org/index.php/rluz/article/view/30990

Pelton, S.L., Hertlein, M.K. (2011). A proposed life cycle for voluntary childfree couples. Journal of Feminist Family Therapy, 23 (1), 39-53.

Polutova, M.A., Zhanbaz, O.O. (2015). The value and motivational attitudes of the Childfree community from the perspective of postmodernism. Bulletin of ZabSU, l (116), 89-100.

Rick, J.M., Meisenbach, R.J. (2017). Social stigma, childfree identities, and work-life balance. Communication and the work-life balancing act: Intersections across identities, genders, and cultures, 205-221.

Rusakova, T., Muss, G., Miroshnikova, D., Zholdasova, M., Goverdovskaya, E. (2019). The project "spiritual and moral culture of students" as the basis for theoretical modeling of spiritual and moral competence of students of Russian and Kazakh universities. Amazonia Investiga, 8 (21), 33-41

Sadovnikova, T.Yu. (2015). The relationship of the ideas of spouses about the functioning of the family with the characteristics of family leadership. Psychological problems of the modern family: a collection of theses, 533-537.

Schneider, L.B. (2007). Family psychology: a textbook for universities. Moscow: Academic Prospect; Yekaterinburg: Business Book.

Serebryakova, T., Koneva, I., Ladykova, O., Begantsova, I., Kostina, O., Egorova, T., Fomina, N. (2019). Manipulation as a form of domestic violence: an empirical approach to the problem. Amazonia Investiga, 8 (21), 767-775.

Sheikh A.A., Suleman N., H.Ali, T.Asghar, S.Rahim, H.Munir. (2019) "I Know Why the Caged Bird Sings": An Illustration of Patriarchal Oppression. Revista de la Universidad del Zulia, 10 (28), 281-294.

Stoykov, A. (2019). Dynamics of communicative tolerance and attitude towards the adoption of another human being in social work students. Amazonia Investiga, 8 (21), 538-550.

Vildanova, S.M. (2017). Trends in the spread of childfree values in Russia and their impact on the crisis of the institution of the family. Monitoring public opinion: Economic and social changes, 3, 192-205. 